\title{
Chemical sanitizers to control biofilms formed by two Pseudomonas species on stainless steel surface
}

\author{
Sanificantes químicos no controle de biofilmes formados por duas espécies de \\ Pseudomonas em superfície de aço inoxidável
}

\author{
Danila Soares CAIXETA ${ }^{1}$, Thiago Henrique SCARPA ${ }^{2}$, Danilo Florisvaldo BRUGNERA ${ }^{1}$, \\ Dieyckson Osvani FREIRE ${ }^{1}$, Eduardo ALVES ${ }^{1}$, Luiz Ronaldo de ABREU ${ }^{1}$, Roberta Hilsdorf PICCOLI ${ }^{1 *}$
}

\begin{abstract}
The biofilm formation of Pseudomonas aeruginosa and Pseudomonas fluorescens on AISI 304 stainless steel in the presence of reconstituted skim milk under different temperatures was conducted, and the potential of three chemical sanitizers in removing the mono-species biofilms formed was compared. Pseudomonas aeruginosa cultivated in skim milk at $28^{\circ} \mathrm{C}$ presented better growth rate $\left(10.4\right.$ log CFU.mL $\left.{ }^{-1}\right)$ when compared with 3.7 and $4.2 \log$ CFU.mL ${ }^{-1}$ for P. aeruginosa and P. fluorescens cultivated at $7{ }^{\circ} \mathrm{C}$, respectively. Pseudomonas aeruginosa formed biofilm when cultivated at $28^{\circ} \mathrm{C}$. However, only the adhesion of $P$. aeruginosa and $P$. fluorescens was observed when incubated at $7^{\circ} \mathrm{C}$. The sodium dichloroisocyanurate was the most efficient sanitizer in the reduction of the adhered P. aeruginosa cells at 7 and $28^{\circ} \mathrm{C}$ and those on the biofilm, respectively. The hydrogen peroxide was more effective in the reduction of adhered cells of $P$. fluorescens at $7^{\circ} \mathrm{C}$.

Keywords: biofilm; P. aeruginosa; P. fluorescens; chemical sanitizers.
\end{abstract}

\section{Resumo}

A capacidade de adesão e formação de biofilme por Pseudomonas aeruginosa e Pseudomonas fluorescens em aço inoxidável AISI 304, na presença de leite desnatado resconstituído sobre diferentes temperaturas foi conduzido e o potencial de três sanificantes químicos na remoção de biofilmes monoespécies foi comparado. Pseudomonas aeruginosa cultivada em leite desnatado a $28^{\circ} \mathrm{C}$ apresentou melhor crescimento (10,4 log UFC. $\mathrm{mL}^{-1}$ ) quando comparado com 3,7 and 4,2 log UFC. $\mathrm{mL}^{-1}$ para P. aeruginosa e P. fluorescens cultivadas a $7{ }^{\circ} \mathrm{C}$, respectivamente. Pseudomonas aeruginosa formou biofilme quando cultivada a $28{ }^{\circ} \mathrm{C}$. Contudo foi observado somente adesão de P. aeruginosa e $P$. fluorescens quando incubada a $7^{\circ} \mathrm{C}$. O dicloroisocianurato de sódio foi o sanificante mais eficiente na redução de células aderidas e em biofilme de $P$. aeruginosa a 7 e $28^{\circ} \mathrm{C}$, respectivamente. O peróxido de hidrogênio foi o mais eficiente na redução de células aderidas de $P$. fluorescens a $7^{\circ} \mathrm{C}$.

Palavras-chave: biofilme; $P$. aeruginosa; P. fluorescens; sanificantes químicos.

\section{Introduction}

The species of the genus Pseudomonas are defined based on several physiological characteristics. They present rather simple nutritional characteristics and grow chemiorganotrophyically in neutral $\mathrm{pH}$ at moderate temperatures around $28^{\circ} \mathrm{C}$. One of the most prominent properties of this genus is the use of a great variety of organic compounds as carbon source and as electron donors for energy generation (MADIGAN; MARTINKO; PARKER, 1997). These bacteria can synthesize a large number of different enzymes, such as proteases and lipases. Many have the capacity of excreting water-soluble pigments that diffuse in the environment (TORTORA; FUNKE; CASE, 2005).

In the dairy food industry, the psychotropic Pseudomonas are the most frequently bacteria associated with deterioration of raw milk stored at refrigerated temperature; $P$. fluorescens is especially being important as a biofilm-forming bacterium capable of contaminating milk previously processed (KIVES; ORGAZ; SANJOSÉ, 2006).

Ubiquitous in nature, the Pseudomonas can be found in the most diverse stages of fluid milk processing (DOGAN; BOOR, 2003), and they can multiply rapidly thus avoiding competition with the food microbiota since they are favored for producing siderophores rendering iron unavailable for the other microorganisms (SANTOS, 1998).

Studies carried out by O'Toole and Kolter (1998) show that biofilms are easily formed on abiotic surfaces by the strain of $P$. fluorescens WCS365. For this to occur, before biofilm formation, the cells must synthesize proteins, which play a major role as extracytoplasmatic (adhesions) interacting with the abiotic surface and osmolarity of the medium directly interfering in the capacity of biofilm forming by this strain.

Received 10/8/2010

Accepted 3/11/2010 (004976)

${ }^{1}$ Departamento de Ciência dos Alimentos, Universidade Federal de Lavras - UFLA, CEP 37200-000, Lavras, MG, Brazil, e-mail: rhpiccoli@dca.ufla.br

${ }^{2}$ Departamento de Fitopatologia, Universidade Federal de Lavras - UFLA, CEP 37200-000, Lavras, MG, Brazil

${ }^{*}$ Corresponding author

DOI: http://dx.doi.org/10.1590/S0101-20612012005000008 
Pseudomonas spp. is the most common psychrotrophic bacteria causing deterioration in fresh milk containing only $10 \%$ of this genus in its microbiota. However, during a prolonged refrigerated process, the Pseudomonas become the predominant microbiota in raw milk since these bacteria have a short production time under refrigeration temperatures compared with other milk microbiota bacteria. Its rapid growth ability combined with refrigeration temperatures provides the Pseudomonas with a great capacity of producing exopolysaccharides, which facilitate biofilm formation (READ; COSTERTON, 1987). Once it is formed, i.e., in its mature form, this biofilm becomes the reservoir of these bacteria easily resisting chemical sanitizers (WANG; JAYARAO, 2001). Different pseudomonas have been isolated from raw milk, with $P$. fluorescens being prevalent and able to reach around $84 \%$ of the number of bacteria found in this product. Wang and Jayarao (2001) obtained various isolates of $P$. fluorescens from milk in bulk milk tank, out of which 80,90 , and $81 \%$ were proteolytic at 7,22 , and $32^{\circ} \mathrm{C}$ and 7,44 , and $7 \%$, were lipolytic at the respective temperatures. Dogan and Boor (2003) isolated 338 Peudomonas from pasteurized raw milk from 4 different raw milk processing plants, and most were identified as $P$. fluorescens and P. putida originating from different sources of contamination.

Studies show that operation conditions affect the adhesive strength of $P$. fluorescens biofilms. Biofilm adhesive strength can be affected by biofilm age, nutrient concentration, planktonic cell concentration, $\mathrm{pH}$, surface roughness, and flow velocity. It increases with flow velocity increase making the biofilm more compact (CHEN; ZHANG; BOTT, 2005) and, consequently, harder to be eliminated.

Pseudomonas aeruginosa is ubiquitous and capable of surviving in hostile environments. It also forms biofilm surfaces due to glycocalyx formation, and its major constituent is alginate (SHIRTLIFF; MADER; CAMPER, 2002). Due to the production of flagellum as a motility mediator, $P$. aeruginosa is capable of forming cell monolayers on abiotic and biotic surfaces after 4 hours of contact. This bacterium is capable of moving in liquids through flagellum, and its motility is due to the presence of pili IV. Although not very common among the pseudomones isolated from raw milk, P. aeruginosa was isolated by Erskine et al. (2002) from milk of cows suspected of being infected with mastitis. Biofilms of $P$. aeruginosa have been reported as extremely resistant to sanitizing agents, and were considered very important when present in the dairy industry (KUDA; YANO; KUDA, 2007).

The use of appropriate and efficient physical or chemical sanitizers in industrial equipment to maintain food quality can prevent biofilm formation and/or reduce microorganism contamination. However, since biofilm elimination on surfaces is a demanding and difficult task, the hygienization process must be analyzed as a whole, optimizing the results and minimizing the costs.

This study aimed to compare biofilm adhesion and formation capacity by Pseudomonas aeruginosa ATCC 27853 and Pseudomonas fluorescens ATCC 13525 on AISI 304 stainless steel, in skim milk reconstituted under different temperatures determining its potentiality of removing the biofilms formed by using the chemical sanitizers hydrogen peroxide $\left(\mathrm{H}_{2} \mathrm{O}_{2}\right)$, sodium dichloroisocianurate, and peracetic acid and determining the most efficient one in removing mono-species biofilms.

\section{Materials and methods}

The present study was developed at the Laboratory of Food Microbiology of the Department of Food Science and at the Laboratory of Electronic Microscopy and Ultra-Structural Analysis (LME) of Microscopy of the Universidade Federal de Lavras (UFLA), MG. $10^{5} . \mathrm{cm}^{-2}$ was the number of adhered cells considered as biofilm in this study (RONNER; WONG, 1993).

\subsection{Standard microorganisms}

The bacteria used in this work were Pseudomonas aeruginosa ATCC 27853 and Pseudomonas fluorescens ATCC 13525.

The number of cells/mL of each culture was quantified using a standard curve. The bacterial cultures were standardized around $10^{5}$ UFC. $\mathrm{mL}^{-1}$.

\subsection{Dimension and hygienization of coupons}

Bacterial adhesion was carried out on $1 \mathrm{~mm}$ thick, $10 \times 20 \mathrm{~mm}$ AISI 304 stainless steel coupons.

The coupons were cleaned individually with $100 \%$ acetone, washed by immersion in 3\% neutral detergent for 1 hour, rinsed with sterilized distilled water, and dried and cleaned with $70 \%$ alcohol (v/v). After hygienization, the coupons were washed again with sterile distilled water, oven-dried for 2 hours at $60{ }^{\circ} \mathrm{C}$, and autoclaved at $121{ }^{\circ} \mathrm{C}$ for 15 minutes (ROSSONI; GAYLARDE, 2000).

\subsection{Adhesion of the bacterial cells}

Mono growth of each bacterium was conducted in Petri dishes (140 $\mathrm{mm}$ diameter) containing around 20 stainless steel coupons. They were immersed in $60 \mathrm{~mL}$ of reconstituted skim milk and inoculated with $10^{5}$ UFC. $\mathrm{mL}^{-1}$ of the culture. $P$. fluorescens cultivations were incubated at 4 and $7{ }^{\circ} \mathrm{C}$ and $P$. aeruginosa cultivations at 7 and $28^{\circ} \mathrm{C}$, under $50 \mathrm{rpm}$ agitation. The coupons were removed at intervals of 48 hours and washed with peptonated water in plates containing sterile reconstituted skim milk. This procedure was carried out five times aiming at complete biofilm formation after 10 incubation days (JOSEPH et al., 2001 with adaptations).

The entire experiment was carried out in three repetitions and the analyses in triplicate.

\subsection{Evaluation of biotransfer potential and determination of sessile cells}

Viable planktonic and sessile cells were quantified after 10 days of incubation by inoculating aliquots of adequate dilutions in Petri dishes containing TSA (Trypticase Soy Agar). The surface spreading technique was applied, and the plates were incubated at $28{ }^{\circ} \mathrm{C}$ for 24 hours. Biotransfer potential (enumeration of planktonic cells) was evaluated by removing 
$1 \mathrm{~mL}$ of milk and plating the adequate dilutions. For the removal of the viable cells from the biofilm, the smear technique was applied using standardized and sterilized swabs.

\subsection{Sanitization}

To test biofilm cell sensitivity, the sanitizers hydrogen peroxide $(5 \% \mathrm{v} / \mathrm{v})$, sodium dichloroisocianurate $\left(200 \mathrm{mg} \cdot \mathrm{L}^{-1} \mathrm{p} / \mathrm{v}\right)$, and peracetic acid $(0.2 \% \mathrm{v} / \mathrm{v})$ were used.

After being removed from each Petri dish, the coupons were immersed in tubes containing $30 \mathrm{~mL}$ of the each sanitizer solution and gently stirred for 1 minute at ambient temperature. The coupons were rinsed in $0.1 \%(\mathrm{v} / \mathrm{v})$ peptonated water. On the coupon surface, where biofilm adhesion or formation had occurred, the smear technique with swabs was applied, which were submitted to vortex for 2 minutes in $0.1 \%(\mathrm{p} / \mathrm{v})$ peptonated water (MARQUES et al., 2007, with adaptation). Serial dilution and plating of adequate TSA aliquots were then carried out to determine the number of viable cells. The plates were incubated at $28{ }^{\circ} \mathrm{C}$ for 24 hours, and the plate standard count was carried out and expressed in CFU.cm ${ }^{-2}$.

\subsection{Coupon analysis by scanning electron microscopy}

The samples were prepared according to Alves (2004).

Electromicrographies from the microorganisms adhered to the stainless steel surface were obtained before and after the use of sanitizers using the scanning electron microscope EVO 040 Leo (ALVES, 2004).

\subsection{Statistical analysis}

The experiment was arranged in a completely randomized design with 3 repetitions. The variable response value was transformed by $\log (x+1)$ to meet the presupposition of normality.

\section{Results and discussion}

The concentration of planktonic cells was determined every 48 hours during the 240 hours cultivation. No significant difference was found between the CFU.mL ${ }^{-1}$ numbers obtained during the different periods of quantification. However, when comparing the concentrations of the initial inoculum of $10^{5}$ CFU.mL ${ }^{-1}$ of each strain, there was a reduction in the number of CFU.mL $\mathrm{mL}^{-1}$ under the cultivation conditions used for both strains, except for $P$. aeruginosa cultivated at $28^{\circ} \mathrm{C}$. It was clear that biotransfer potential of microorganisms to milk occurred since there was growth of the strains used in the sterilized milk substituted every 48 hours. Thus, the CFU detected came from cells detached from the stainless steel coupons, which were washed for the removal of the non-adhered cells before being replaced for new cultivation. This fact was related to Aeromonas hydrophila and Staphylococcus aureus (BOARI et al., 2009) and Listeria monocytogenes (OLIVEIRA et al., 2010).

The final mean concentration of $P$. aeruginosa in milk was 10.4 and $3.7 \log$ CFU.mL ${ }^{-1}$, when cultivated at 28 and $7{ }^{\circ} \mathrm{C}$, respectively, showing that at its optimum cultivation temperature, greater cell adherence occurred and, consequently, greater bio-transfer, as observed in Figure 1 and by scanning electromicrography (Figure 2 and 3). Pseudomonas aeruginosa is a mesophyllic bacterium, which is mainly related with human and animal diseases, with optimum growth temperature at $37^{\circ} \mathrm{C}$ and consequent cell concentration drop at $7{ }^{\circ} \mathrm{C}$ thus showing little adaptation at low temperatures. Pseudomonas aeruginosa has been isolated from milk stored in raw milk cooling tanks ( 4 to $7^{\circ} \mathrm{C}$ ), but under these storage conditions, its growth was not favored (ALATOSSAVA; ALATOSSAVA, 2006). Similarly to $P$. aeruginosa, no significant difference was observed in the number of CFU.mL ${ }^{-1}$ for $P$. fluorescens during the 240 hours of cultivation with a reduction in the number of CFU.mL $\mathrm{mL}^{-1}$ of $P$. fluorescens when cultivated at $7{ }^{\circ} \mathrm{C}$ obtaining 4.2 and $\log \mathrm{CFU} \cdot \mathrm{mL}^{-1}$ and no bacterium growth at $4{ }^{\circ} \mathrm{C}$. Although it is widely known that $P$. fluorescens develops well from $0^{\circ} \mathrm{C}$, the strain studied did not adapt well to the conditions provided at 4 and $7{ }^{\circ} \mathrm{C}$. It must be pointed out that it was isolated from pre-filtration water tanks. Broeze, Solomon and Pope (1978) reported that $P$. fluorescens ATCC 13525, which was used in this experiment, has a lag phase of 4 hours and generation time of 9 hours when grown in nutrient liquid and incubated at $5{ }^{\circ} \mathrm{C}$; a fact that justifies the low concentration of cells obtained at $7^{\circ} \mathrm{C}$ since the incubation cycle for each growth cycle was 48 hours and the initial inoculum was constituted by the cells adhered on the stainless steel coupon.

The growth of bacteria of the genus Pseudomonas in milk has been reported to cause organoleptic alterations in the product. $P$. fluorescens is the most common bacteria associated to such alterations. However, due to its low adaptation to the growing conditions and decrease in the number of viable cells, no alterations were observed in the organoleptic characteristics of milk. Not only did the strain used in this experiment fail to deteriorate milk at low temperatures, but also the P. fluorescens strain isolated from the bulk milk tank was not capable of promoting proteolysis detectable in litmus milk when incubated at 2 and $5{ }^{\circ} \mathrm{C}$. This activity was detected only after 14 days of growth after observation at the beginning of its multiplication after 4 days of incubation (JUFFS, 1976). The production of extra-cellular lipases by 2D strain P. fluorescens, as the protease of other bacterium isolates, was also influenced by the incubation temperature. Studies showed that when the bacterium is cultivated from 10 to $30^{\circ} \mathrm{C}$ the highest lipolysis occurs at $20^{\circ} \mathrm{C}$

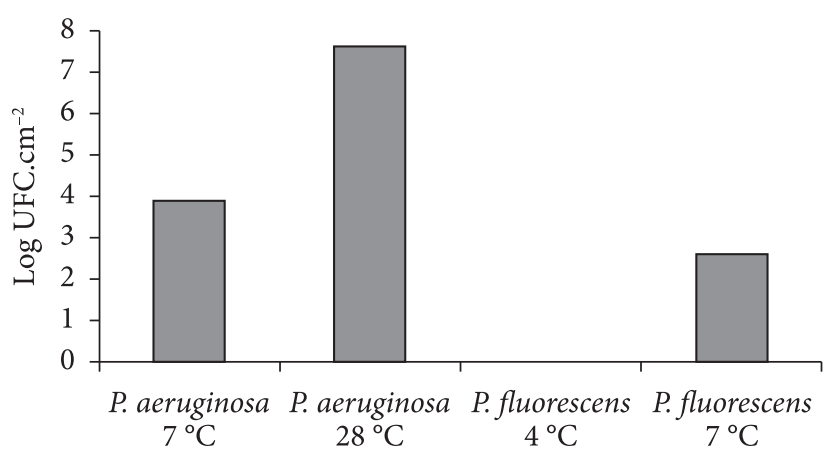

Figure 1. Mean values of biofilm adhesion and formation by Pseudomonas spp. transformed by $\log (x+1)$, at different temperatures after 10 days of incubation. 

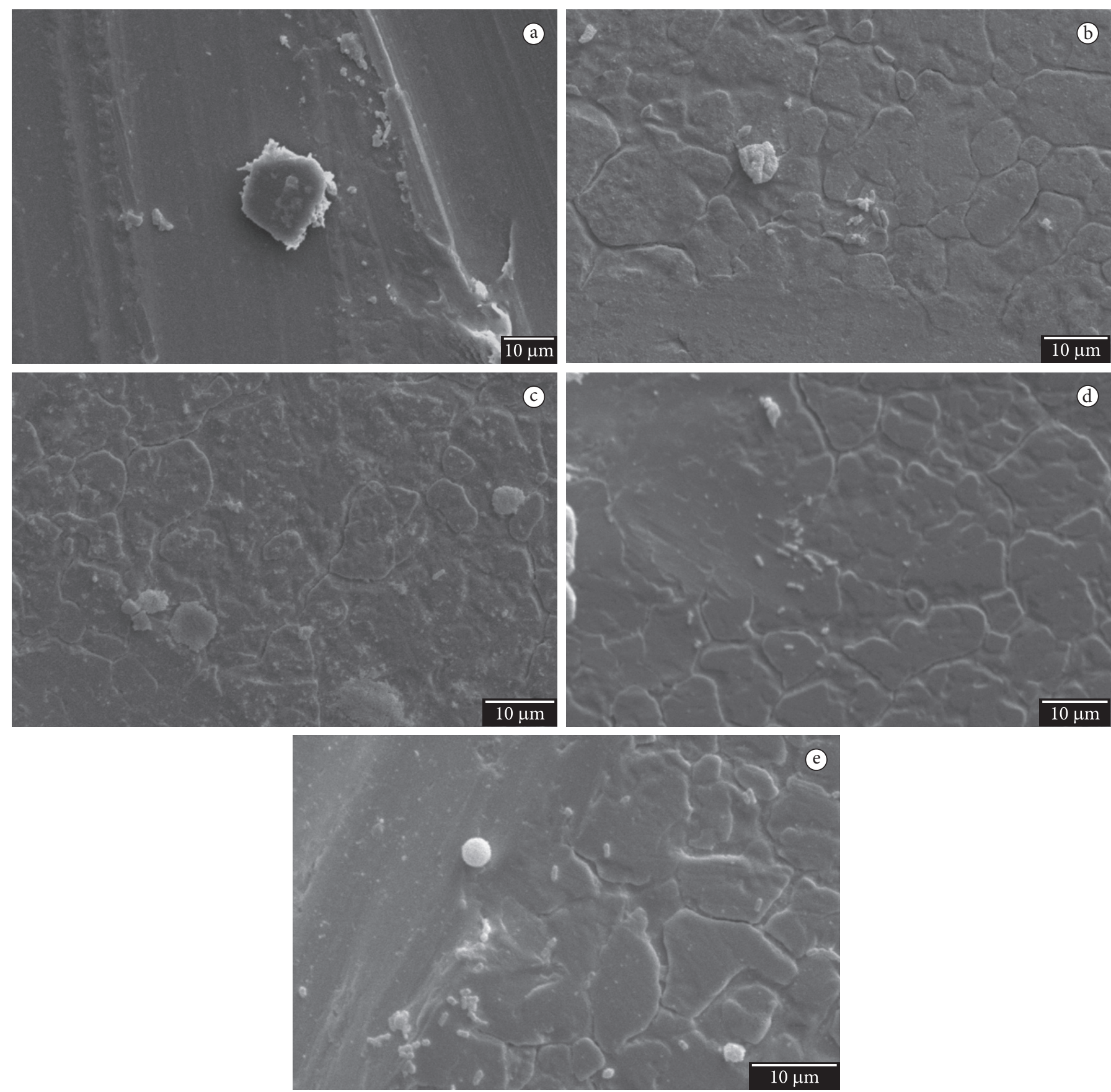

Figure 2. Scanning electronic electromicography of biofilm formation by $P$. aeruginosa grown in skim milk reconstituted at $7^{\circ} \mathrm{C}$ in stainless steel at: a) 2, b) 4, c) 6 , d) 8 , and e) 10 days of incubation.

after 24 hours cultivation (MAKHZOUM; KNAPP; OWUSU, 1995). On the other hand, P. aeruginosa, at both temperatures caused milk to turn yellowish and have an unpleasant odor, which is likely due to the production of lipases and proteases that promote milk alteration at a concentration above $6 \log \mathrm{CFU} \cdot \mathrm{mL}^{-1}$ (CHAMPAGNE et al., 1994).

Based on the fact that bacteria and other microorganisms have a natural tendency to adhere to surfaces as a survival mechanism, with bacterial colonization of solid surfaces being described as a basic and natural strategy in a wide range of environments (CAPPELLO; GUGLIELMINO, 2006), one can say that the planktonic cells, detected in milk after the removal of the inoculum-added milk following 48 hours cultivation, originated from those that remained adhered to the stainless steel coupon. Bacteria adhesion to the surface depends on microbiological, physical, chemical, and material-related parameters. Hence, surface topography has been extensively studied since hidden microorganisms may not be properly hygienized and can later contaminate or re-contaminate food products during processing (HILBERT et al., 2003). Scanning electronic electromicrography of the stainless steel coupons used in this experiment showed that these coupons present many 
imperfections (Figure 2, 3 and 4) facilitating cell adherence even under inadequate conditions of growth.

Pseudomonas aeruginosa formed biofilm on stainless steel when cultivated in skim milk reconstituted at $28^{\circ} \mathrm{C}$, the optimum temperature for its growth. However, this bacterium was not capable of forming biofilm when cultivated at $7^{\circ} \mathrm{C}$ after 240 hours of cultivation, with only an adhesion of $3.9 \mathrm{log}$ CFU.cm ${ }^{-2}$ (Figure 1). This fact must be considered according to Andrade, Bridgeman and Zottola (1998) and Ronner and Wong (1993), but based on Wirtanen, Husmark and Mattila-Sandholm (1996), one can say that $P$. aeruginosa formed biofilm under these conditions.
Considering that the concentration of the adhered cells $/ \mathrm{cm}^{2}$ must be of $10^{5}$ (RONNER; WONG, 1993), P. fluorescens did not form biofilm either when cultivated at $7^{\circ} \mathrm{C}$ since the UFC. $\mathrm{cm}^{-2}$ concentration was $2.6 \mathrm{log}$.

Evaluating the cultivation time influence on the two temperatures studied for $P$. aeruginosa, no significant difference was found ( $\mathrm{p}>0.05)$ in the number of log CFU.cm ${ }^{-2}$, a fact also observed for $P$. fluorescens at $7{ }^{\circ} \mathrm{C}$. However, an analysis based on scanning electronic micrography reveals differences between cultivation time and the temperatures studied for $P$. aeuruginosa at both temperatures and P. fluorescens
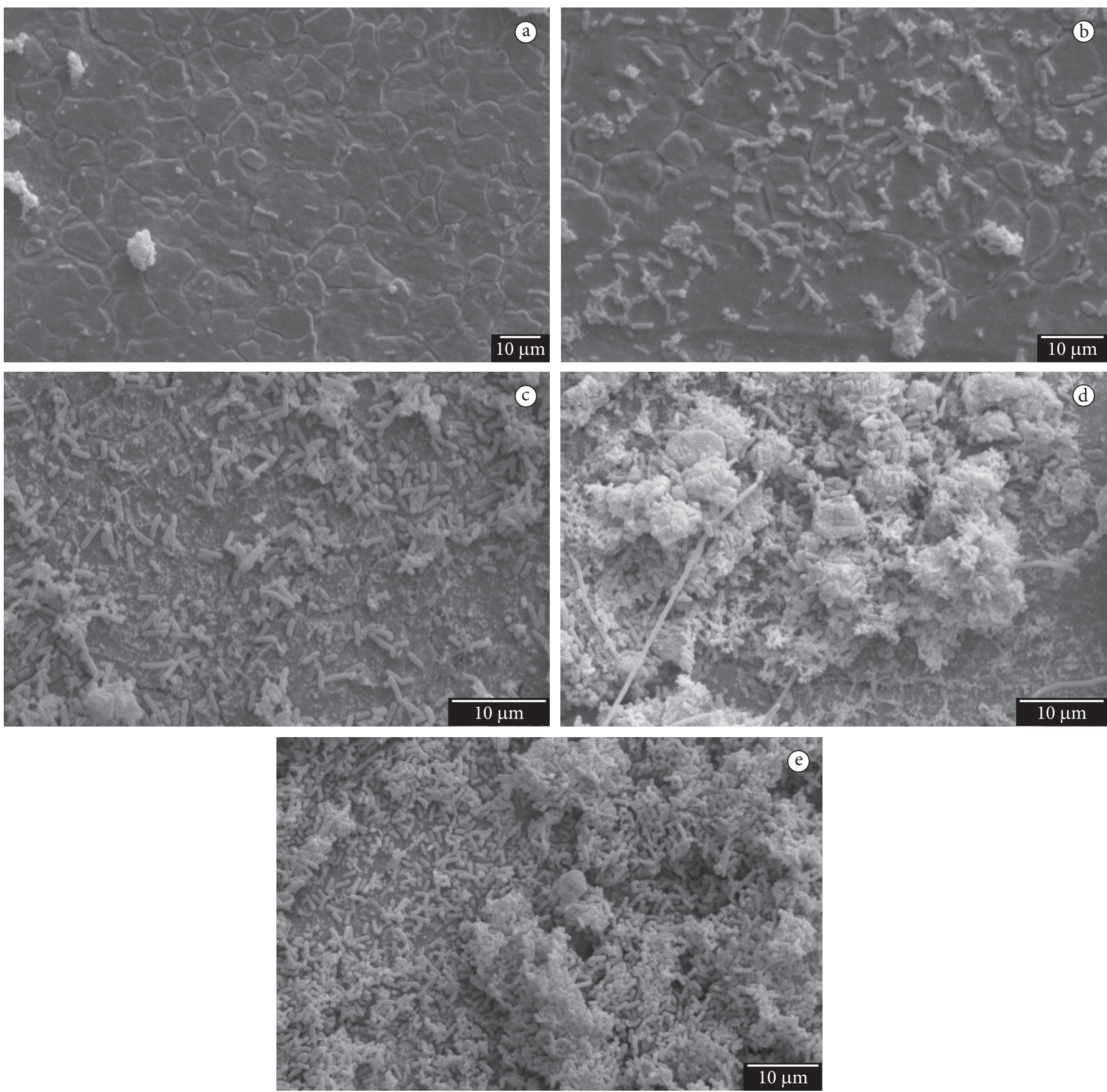

Figure 3. Scanning electronic electromicography of adhesion of $P$. aeruginosa cultivated in skim milk reconstituted at $28^{\circ} \mathrm{C}$ in stainless steel at: a) 2 , b) 4 , c) 6 , d) 8 , and e) 10 days of incubation. 
at $7{ }^{\circ} \mathrm{C}$ (Figure 2, 3, and 4). Although still fully discussed, scanning electronic microscopy has been widely used on biofilm studies, especially Environmental Scanning Electronic Microscopy (ESEM), with the capacity to preserve some of the structures associated with biological samples which remain in their hydrated and viable state (KUMAR; ANAND, 1998). In order to study the $P$. fluorescens adhesion, the scanning electronic microscopy was used for Careli et al. (2009). They observed that the microtopography characteristics of different surfaces (marble, granite, stainless steel, polyvinyl chloride, polyurethane, and silicone-coated cloth) were important for $P$. fluorescens adhesion.

Some of the advantages of biofilm formation are the capacity of the polymeric matrix of capturing and concentrating a large number of environmental nutrients, such as carbon, nitrogen, and phosphate; the capacity of resisting removal strategies, such as microbial agents, release of host phagocytes, oxygen radicals, and protease defense; and the ability of dispersing
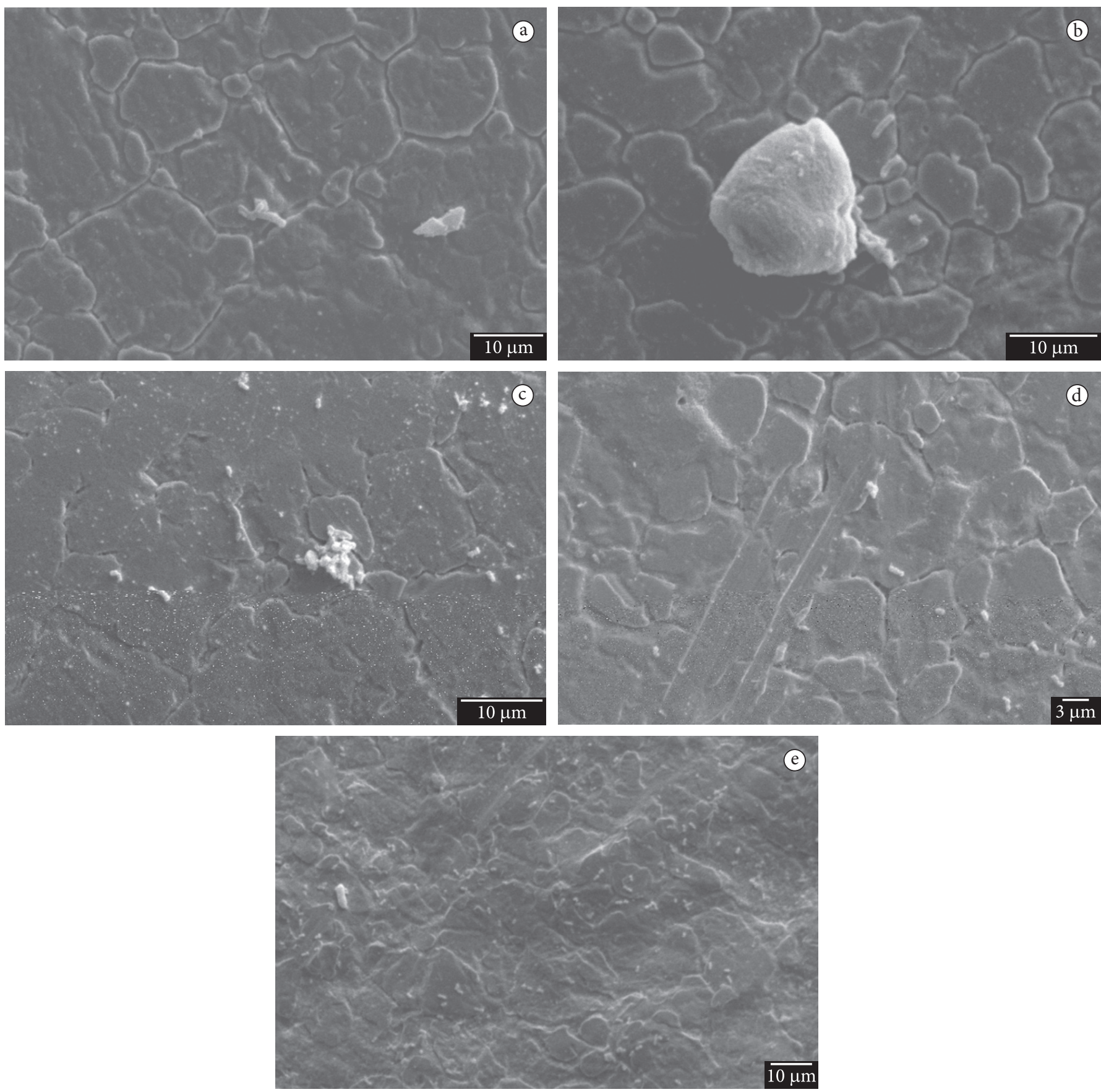

Figure 4. Scanning electronic electromicography of adhesion of $P$. fluorescens when cultivated in skim milk reconstituted at $7^{\circ} \mathrm{C}$ in stainless steel at: a) 2 , b) 4, c) 6 , d) 8 , and e) 10 days of incubation. 
through deadhesion; the micro-colonies are able to detach under mechanic fluid or by genetic response (SHIRTLIFF; MADER; CAMPER, 2002).

Once the adhesion capacity of the cells of the two pseudomonas strains is analyzed, their resistance against sanitizers must be evaluated. Figures 5 and 6 show the effect of the sanitizing agents sodium dichloroisocianurate, hydrogen peroxide, and peracetic acid on the cells of $P$. aeruginosa adhered to stainless steel when cultivated at 7 and $28^{\circ} \mathrm{C}$, respectively.

No significant effect ( $p>0.05$ ) was found in the reduction of the number of cells adhered or on P. aeruginosa biofilm by the sanitizers used. However, one must bear in mind that the adhered cells were exposed to the sanitizing agents for only 1 minute. Several experiments show that, even under exposure to antimicrobial agents for over 10 minutes, the eradication of

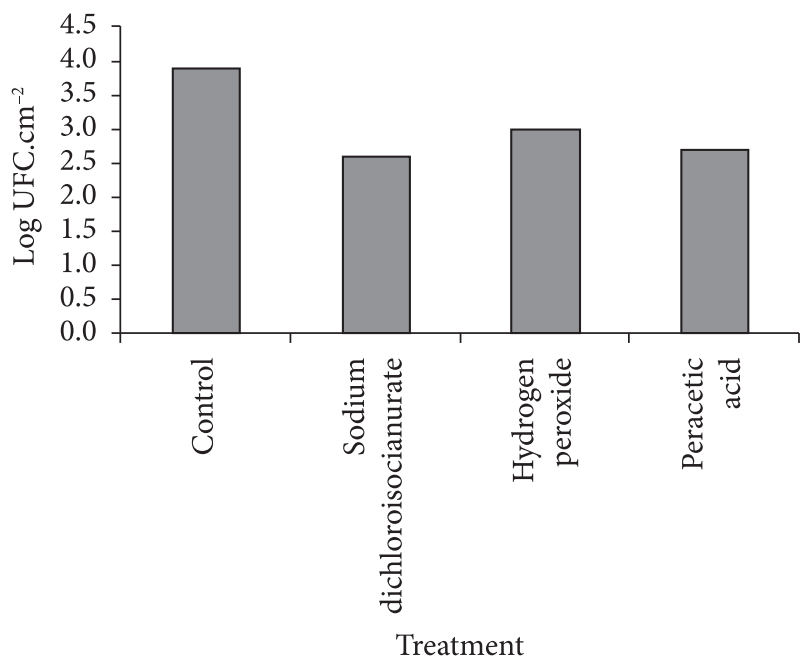

Figure 5. Mean values of $\log \mathrm{UFC} . \mathrm{cm}^{-2}$ of $P$. aeruginosa after 10 incubation days in skim milk at $7^{\circ} \mathrm{C}$ submitted to sanitizer treatment for 1 minute.

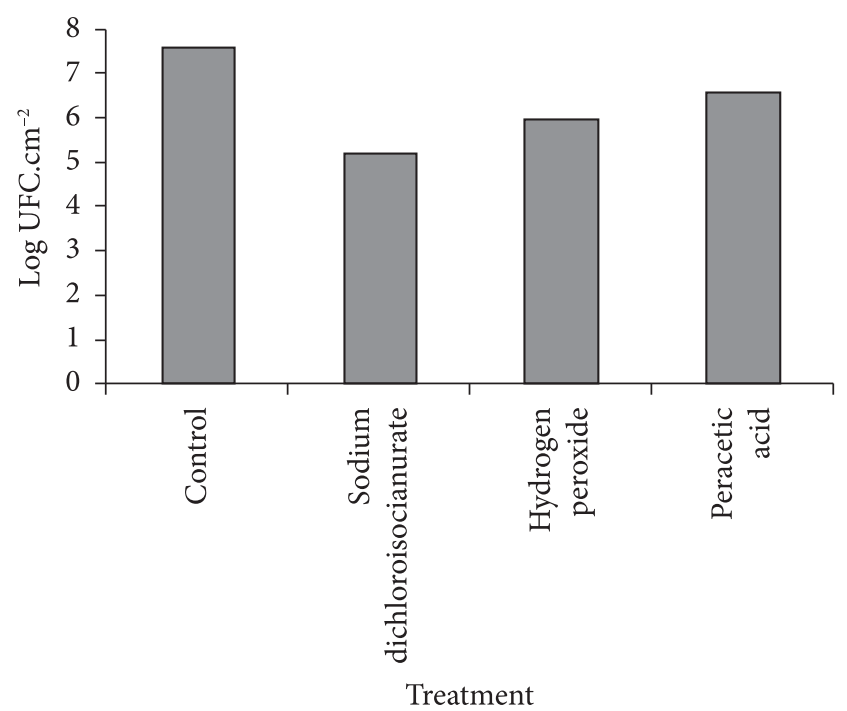

Figure 6. Mean values of $\log$ UFC. $\mathrm{cm}^{-2}$ of $P$. aeruginosa after 10 days of incubation in skim milk at $28{ }^{\circ} \mathrm{C}$ submitted to sanitizer treatment for 1 minute. a mature biofilm cannot be obtained. Chambless, Hurd and Stewart (2006) showed that due to the slow penetration of antimicrobial agents, the biofilm has a good protection up to 15 hours of exposure to the antimicrobial agent; around 50 hours of exposure are necessary for the biofilm to be eradicated. Therefore, the short time of biofilm exposure to the sanitizer can show the same efficiency of the sanitizers exposed for 1 minute only since there was a reduction of $1.3 ; 1.2$, and $0.9 \mathrm{log}$ cycles in the cells adhered at $7{ }^{\circ} \mathrm{C}$ by the exposure to solutions of sodium dichloroisocianurate, peracetic acid, and hydrogen peroxide, respectively.

Similarly, when the biofilm formed by $P$. aeruginosa at $28^{\circ} \mathrm{C}$ was treated by the sanitizers, there were reductions of 2.4 ; 1.0 , and $1.6 \mathrm{log}$ cycles of CFU.cm ${ }^{-2}$ by the solutions of sodium dichloroisocinate, peracetic acid, and hydrogen peroxide, respectively. Although $P$. aeruginosa produces catalase, being capable of eliminating hydrogen peroxide, there are reports that the capacity of penetration of hydrogen peroxide into the biofilm of $P$. aeruginosa is small due to reaction-diffusion interactions (STEWART et al., 2000).

The antibacterial activity of chlorine-based compounds is formed when chlorine or the hypochlorite components are added to the water and hypocholorus acid. The effect of hypochlorite is based on the penetration of chemicals into the cell and chemical reactions in the cellular protoplasm. The bactericidal effect of chloride is based on the oxidative activity in systems of essential cell enzymes (WIRTANEN et al., 2001). Microbial biofilms present great resistance to active chlorine; thus, for a significant reduction in the number of bacteria in the film to occur, a concentration of $1000 \mathrm{ppm}$ is necessary, while for the planktonic cells, $10 \mathrm{ppm}$ is necessary (NORWOOD; GILMOUR, 2000). In spite of that, active chlorine is frequently required as the first option against biofilm formation since, besides killing the microorganisms, it is also known for removing expolysacharides from the surface making adherence of new bacteria difficult (MEYER, 2003). The results obtained by Rossoni and Gaylarde (2000) corroborate the results obtained in this study. These authors verified greater reductions in the number of stainless steel-adhered cells of E. coli, S. aureus and P. fluorescens, using hypochlorite at 100 or $200 \mathrm{ppm}$.

Differently from $P$. aeruginosa, the adhered cells of P. fluorescens were more affected by hydrogen peroxide than by sodium dichloroisocianurate. Although no significant difference was found between the sanitizers studied, there was a reduction in $\log$ cycles of $0.4 ; 1.4$, and 0.7 for sodium dichloroisocianurate, hydrogen peroxide, and peracetic acid, respectively (Figure 7).

It is believed that due to the high hydrogen peroxide diffusion inside the cell and to the low population density, the endogenous catalase was not sufficiently active to protect the individual cells (BRUL; COOTE, 1999).

The hydrogen peroxide effect is based on the production of free radicals that affect the polysaccharides and glycol-proteins in the biofilm. Wirtanen et al. (2001) showed that the peroxidebased sanitizers were effective permeabilizers.

According to Chapman (2003), an additional survival mechanism of oxidant-exposed cells is the phenotypic tolerance 


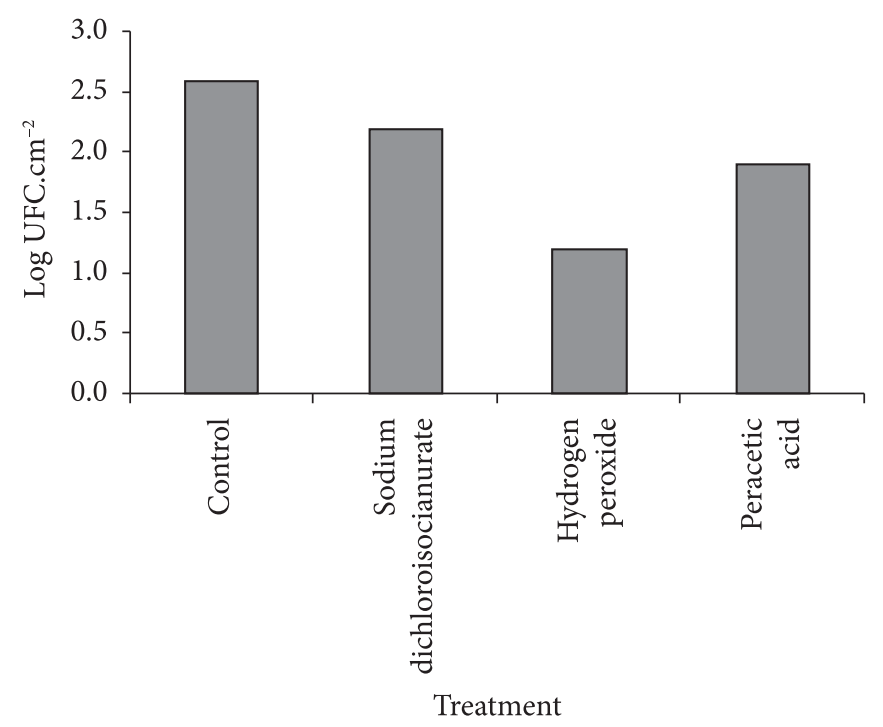

Figure 7. Mean values of $\log \mathrm{UFC} . \mathrm{cm}^{-2}$ of $P$. fluorescens $7^{\circ} \mathrm{C}$ according to the chemical sanitizer used to control it.

obtained in the biofilm cell cultivation. The antioxidant protection provided by biofilm cell growth is due to the oxidant reactivity with the biofilm components, including extra-cellular polymeric substances and the cell itself. Therefore, the oxidant is consumed before reacting with the deepest cells in the biofilm due to the reaction mechanism of kinetics diffusion. On the other hand, the diffusion reduction mechanism is not sufficient to protect thinner biofilms, which may allow the induction of other defense mechanisms by the cell such as the oxR, which repairs the damage caused by oxygen radicals.

Recent studies have shown that, after adhesion or external stress, such as osmotic or thermal shock or disinfection, stressed bacteria are capable of remaining in a non-cultivatable but viable state. Bacteria can remain dormant; thus their physiological state may preserve their virulence. Dormant bacteria cannot be detected by cultivation, but even so they can be very dangerous (FUSTER-VALLS et al., 2008).

\section{Conclusions}

Biofilm formation on stainless steel occurred only by $P$. aeruginosa when incubated at $28^{\circ} \mathrm{C}$ and adhesion of $P$. aeruginosa and $P$. fluorescens when incubated at $7{ }^{\circ} \mathrm{C}$.

The sanitizer sodium dichloroisocianurate was the most efficient in reducing adhesion and biofilm by $P$. aeruginosa at 7 and $28^{\circ} \mathrm{C}$, respectively. On the other hand, hydrogen peroxide was the most effective in reducing $P$. fluorescens adhesion at $7{ }^{\circ} \mathrm{C}$.

\section{References}

ALATOSSAVA, P.; ALATOSSAVA, T. Phenotypic characterization of raw milk-associated psychrotrophic bacteria. Microbiological Research, v. 161, n. 4, p. 334-346, 2006. http://dx.doi.org/10.1016/j. micres.2005.12.004

ALVES, E. Curso: introdução à microscopia eletrônica de varredura e de transmissão. Lavras: Universidade Federal de Lavras, 2004.

ANDRADE, N. J.; BRIDGEMAN, T. A.; ZOTTOLA, E. A. Bacteriocidal activity of sanitizers against Enterococcus faecium attached to stainless steel as determined by plate count and impedance methods. Journal of Food Protection, v. 61, n. 7, p. 833-838, 1998.

BOARI, C. A. et al. Formação de biofilme em aço inoxidável por Aeromonas hydrophila e Staphylococcus aureus usando leite e diferentes condições de cultivo. Ciência e Tecnologia de Alimentos, v. 29 , n. 4 , p. $886-895,2009$. http://dx.doi.org/10.1590/S010120612009000400029

BROEZE, R. J.; SOLOMON, C. J.; POPE, D. H. Effects of low temperature on in vivo and in vitro protein synthesis in Escherichia coli and Pseudomonas fluorescens. Journal of Bacteriology, v. 134, n. 3, p. 861-874, 1978.

BRUL, S.; COOTE, P. Preservative agents in foods: mode of action and microbial resistance mechanisms. International Journal of Food Microbiology, v. 50, n. 1-2, p. 1-17, 1999. http://dx.doi.org/10.1016/ S0168-1605(99)00072-0

CAPPELLO, S.; GUGLIELMINO, S. P. P. Effects of growth temperature on polystyrene adhesion of Pseudomonas aeruginosa ATCC 27853. Brazilian Journal of Microbiology, v. 37, n. 3, p. 205-207, 2006. http://dx.doi.org/10.1590/S1517-83822006000300001

CARELI, R. T. et al. The adherence of Pseudomonas fluorescens to marble, granite, synthetic polymers, and stainless steel. Ciência e Tecnologia de Alimentos, v. 29, n. 1, p. 171-176, 2009. http://dx.doi. org/10.1590/S0101-20612009000100026

CHAMBlESS, J. D.; HURD, S. M.; STEWART, P. S. A threedimensional computer model of four hypothetical mechanisms protecting biofilms from antimicrobes. Application Environmental Microbiology, v. 72, n. 3, p. 2005-2013, 2006. PMid:16517649. PMCid:1393201. http://dx.doi.org/10.1128/AEM.72.3.20052013.2006

CHAMPAGNE, C. P. et al. Psychrotrophs in dairy products: their effects and their control. Critical Reviews in Food Science and Nutrition, v. 34, n. 1, p. 1-30, 1994. http://dx.doi. org/10.1080/10408399409527648

CHAPMAN, J. S. Disinfectant resistance mechanisms, crossresistance, and co-resistance. International Biodeterioration and Biodegradation, v. 51, n. 4, p. 271-276, 2003. PMCid:373060. http:// dx.doi.org/10.1016/S0964-8305(03)00044-1

CHEN, M. J.; ZHANG, Z.; BOTT, T. R. Effects of operating conditions on the adhesive strength of Pseudomonas fluorescens biofilms in tubes. Colloids and Surfaces B: Biointerfaces, v. 43, n. 2, p. 61-71, 2005. PMid:15913966. http://dx.doi.org/10.1016/j. colsurfb.2005.04.004

DOGAN, B.; BOOR, K. J. Genetic diversity and spoilage potentials among Pseudomonas spp. isolated from fluid milk products and dairy processing plants. Applied and Environmental Microbiology, v. 69, n. 1, p. 130-138, 2003. http://dx.doi. org/10.1128/AEM.69.1.130-138.2003

ERSKINE, R. J. et al. Trends in antibacterial susceptibility of mastitis pathogens during a seven-year period. Journal of Dairy Science, v. 85 , n. 5,p. 1111-1118, 2002. http://dx.doi.org/10.3168/jds.S00220302(02)74172-6

FUSTER-VALLS, N. et al. Effect of different environmental conditions on the bacteria survival on stainless steel surfaces. Food Control, v. 19, n. 3, p. 308-314, 2008. http://dx.doi.org/10.1016/j. foodcont.2007.04.013

HILBERT, L. R. et al. Influence of surface roughness of stainless steel on microbial adhesion and corrosion resistance. International Biodeterioration and Biodegradation, v. 52, n. 1, p. 173-185, 2003.

JOSEPH, B. et al. Biofilm formation by Salmonella spp. On food contact surfaces and their sensitivity to sanitizers. International Journal 
of Food Microbiology, v. 64, n. 3, p. 367-372, 2001. http://dx.doi. org/10.1016/S0168-1605(00)00466-9

JUFFS, H. S. Effects of temperature and nutrients on proteinase production by Pseudomonas fluorescens and Ps. aeruginosa in broth and milk. Journal of Applied Microbiology, v. 40, n. 1, p. 23-32, 1976. http://dx.doi.org/10.1111/j.1365-2672.1976.tb00587.x

KIVES, J.; ORGAZ, B.; SANJOSÉ, C. Polysaccharide differences between planktonic and biofilm-associated-EPS from Pseudomonas fluorescens B52. Colloids and Surfaces B: Biointerfaces, v. 52, p. 123-127, 2006. PMid:16757156. http://dx.doi.org/10.1016/j. colsurfb.2006.04.018

KUDA, T.; YANO, T.; KUDA, M. Resistances to benzalkonium chloride of bactéria dried with food elements on stainless steel surface. LWTFood Science and Technology, v. 41, n. 6, p. 988-993, 2007. http:// dx.doi.org/10.1016/j.lwt.2007.06.016

KUMAR, C. G.; ANAND, S. K. Significance of microbial biofilms in food industry: a review. International Journal of Food Microbiology, v. 42, p. 9-27, 1998. http://dx.doi.org/10.1016/ S0168-1605(98)00060-9

MADIGAN, M. T.; MARTINKO, J. M.; PARKER, J. Brock biology of microorganisms. 8. ed. London: Prentice Hall, 1997.

MAKHZOUM, A.; KNAPP, J. S.; OWUSU, R. K. Factors affecting growth and extracellular lipase production by Pseudomonas fluorescens 2D. Food Microbiology, v. 12, n. 1, p. 277-290, 1995. http://dx.doi.org/10.1016/S0740-0020(95)80108-1

MARQUES, S. C. et al. Formation of biofilms by Staphylococcus aureus on stainless steel and glass surfaces and its resistance to some selected chemical sanitizers. Brazilian Journal of Microbiology, v. 38, n. 3, p. 538-543, 2007. http://dx.doi.org/10.1590/S151783822007000300029

MEYER, B. Approaches to prevention, removal and killing of biofilms. International Biodeterioration and Biodegradation, v. 51, n. 4, p. 249-253, 2003. PMCid:373060. http://dx.doi.org/10.1016/S09648305(03)00047-7

NORWOOD, D. E.; GILMOUR, A. The growth and resistance to sodium hypochloride of Listeria monocytogenes in a steady-state multispecies biofilm. Journal of Applied Microbiology, v. 88, n. 3, p. 512-520, 2000. PMid:10747232. http://dx.doi.org/10.1046/j.1365-2672.2000.00990.x

O 'TOOLE, G.A; KOLTER, R. Initiation of biofilm formation in Pseudomonas fluorescens WCS365 proceeds via multiple, convergent signalling pathways: a genetic analysis. Molecular Microbiology, v. 28, n. 3, p. 449-461, 1998.
OLIVEIRA, M. M. M. et al. Biofilm formation by Listeria monocytogenes on stainless steel surface and biotransfer potential. Brazilian Journal of Microbiology, v. 41, n. 1, p. 97-106, 2010. http://dx.doi. org/10.1590/S1517-83822010000100016

READ, R. R.; COSTERTON, J. W. Purification and characterization of adhesive exopolysaccharides from Pseudomonas putida and Pseudomonas fluorescens. Canadian Journal of Microbiology, v. 3, n. 12, p. 1080-1090, 1987.

RONNER, A. B.; WONG, A. C. L. Biofilm development and sanitizer inactivation of Listeria monocytogenes and Salmonella Thyphimurium on stainless steel and buna-n rubber. Journal of Food Protection, v. 56, n. 9, p. 750-758, 1993.

ROSSONI, E. M. M.; GAYLARDE, C. C. Comparison of sodium hypochlorite and peracet acid as sanitising agents for stainless steel food processing surfaces using epifluorescence microscopy. International Journal of Food Microbiology, v. 61, n. 1, p. 81-85, 2000. http://dx.doi.org/10.1016/S0168-1605(00)00369-X

SANTOS, E.S. Microbiota do leite pasteurizado resfriado inoculado com Pseudomonas fluorescens. 1998. 57 f. Dissertação (Mestrado em Ciência dos Alimentos)-Universidade Federal de Lavras, Lavras, 1998.

SHIRTLIFF, M. E.; MADER, J. T.; CAMPER, A. K. Molecular interactions in biofilms. Chemistry and Biology, v. 9, n. 8, p. 859-871, 2002. http://dx.doi.org/10.1016/S1074-5521(02)00198-9

STEWART, P. S. et al. Effect of catalase on hydrogen peroxide penetration into Pseudomonas aeruginosa biofilms. Applied Enviromment Microbial, v. 66, n. 2, p. 836-838, 2000. PMid:10653761. PMCid:91906. http://dx.doi.org/10.1128/ AEM.66.2.836-838.2000

TORTORA, G. J.; FUNKE, B. R.; CASE, C. L. Microbiologia. 8. ed. Porto Alegre: Artmed, 2005.

WANG, L.; JAYARAO, B. M. Phenotypic and genotypic characterization of Pseudomonas fluorescens isolated from bulk tank milk. Journal of Dairy Science, v. 84, n. 6, p. 1421-1429, 2001.

WIRTANEN, G.; HUSMARK, U.; MATTILA-SANDHOLM, T. Microbial evaluation of the biotransfer potential from surfaces with Bacillus biofilms after rinsing and cleaning procedures in closed food-processing systems. Journal of Food Protection, v. 59, n. 7, p. 727-733, 1996.

WIRTANEN, G. et al. Microbiological methods for testing disinfectant efficiency on Pseudomonas biofilm. Colloids e Surfaces, v. 20, n. 1, p. 37-50, 2001. http://dx.doi.org/10.1016/S0927-7765(00)00173-9 